\title{
ANNIVERSARIES AND DATES
}

\section{Professor of Chemistry Edmunds Lukevics (1936-2009)}

Edmunds Lukevics was born in 1936 in Liepaja, Latvia. He developed a deep interest in chemistry during high school years. In 1953 he entered the University of Latvia, and in 1956 published his first paper. After receiving B. Sc. with four publications, Edmunds got his $\mathrm{PhD}$ in 1966 and Dr. habil. chem. in 1973 from the Latvian Academy of Sciences.

Edmunds Lukevics, a pioneer of organosilicon and organogermanium chemistry in Latvia, was known worldwide for his important contributions to main group organoelement chemistry. He published nearly 2000 scientific papers and patents. Edmunds had a very broad spectrum of scientific interests, including development of methods for the synthesis and functionalization of organosilicon and organogermanium derivatives of heterocycles; study of hydrosilylation and hydrogermylation reactions, synthesis and investigation of properties of pentaand hexacoordinated organosilicon and organogermanium derivatives; application of phase-transfer catalysis and ultrasonic irradiation in organometallic synthesis; synthesis of biologically active organosilicon and organogermanium compounds and studies of their properties.

From 1982 till 2003 Edmunds Lukevics served as director of the Latvian Institute of Organic Synthesis. Edmunds Lukevics was elected to the Latvian Academy of Sciences in 1987 and to the New York Academy of Sciences in 1993. His outstanding scientific achievements were recognized by numerous National and International Awards, including the Latvian Academy of Sciences Gustavs Vanags Prize (in Chemistry, 1986), the Latvian Academy of Sciences Grand Medal (1996), Silver Medal of Milan University (1996), International Man of the Year (The International Biographical Centre of Cambridge, England, 1992-1993, 1994-1995), Man of the Year (The American Biographical

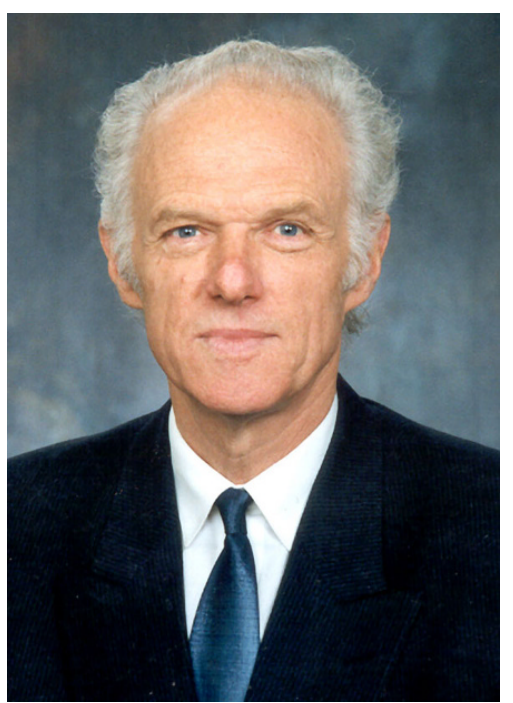

Institute, 1994, 2005), the Cabinet of Ministers of the Republic of Latvia Prize (2004), American Medal of Honor (ABI, 2005), Gold Medal for Latvia (ABI, 2006), The Plato Award (IBC, 2006), Man of Achievement (ABI, 2007), and many others.

Professor Lukevics' contribution to the Journal "Chemistry of Heterocyclic Compounds" was unmatched. Thus, being the Editor-in-Chief of for 25 years, he thoroughly reviewed all manuscripts submitted to the Journal. Evidently, the outcome of this gigantic effort was reflected in steadily improvement of the quality of the Journal. This also helped establishing the national and international scientific reputation of the Latvian Institute of Organic Synthesis.

Edmunds Lukevics was an excellent mentor. Being a very gentle and patient person, he would let his $\mathrm{PhD}$ students to come up with their own solution to the problem. This style was essential for their scientific growth. Furthermore, Edmunds Lukevics was famous for placing his people to the Postdoctoral positions in the top labs around the Globe. Thus, it is not surprising that his former students are now at the top academic and industrial positions not only in Latvia, but also in United States, Canada, United Kingdom, Israel, and other countries.

Vladimir Gevorgyan, Former Prof. Lukevics PhD student University of Illinois at Chicago, USA

With this note the Editorial team of the "Chemistry of Heterocyclic Compounds" Journal, staff of the Latvian Institute of Organic Synthesis, colleagues, and friends from various countries with gratitude commemorate Edmunds Lukevics on the occasion of his 80th birth anniversary. 